\title{
Socrates: Philosophy applied to Education - Search for Virtue
}

\author{
By Gustavo Araújo Batista*
}

\begin{abstract}
This text shows itself as one of the results of a theoretical or bibliographical research, whose purpose is to explain this finality of the Socratic thinking, that is: the applying of philosophy into education, as the most efficient way of breeding the individual for a personal and collective existence which be, overall, reflexive. The present article goes in search of theoretical supporters, such as: Brun (1984), Cambi (1999), Dinucci (2009) and Plato (2004). Once upon the socratic philosophy has been revealed itself a very fertile terrain to the spread of investigations of philosophical-educational order, this text also occupies itself of directing it to some considerations about the contribution of the socraticism to the educator's ethical-political auto-breeding, showing as its main result that the Socrates' personality and reflection constitute an immortal example of philosopher, educator and virtue defender, whose dialogical method is still valued to the breeding of the contemporary educator.
\end{abstract}

Keywords: dialogue, education, philosophy, Socrates virtue

\section{Introduction}

Socrates (471/470-399 B.C) is not only considered one of the main standards of philosophers; he is also one into the quality of one of the great educators of mankind; the truth of that affirmation is based on the fact according to which at least along the trajectory of western civilization, philosophers and educators from the most different eras and places sometimes invocate him such as one of their irrefutable icons. However, it is still necessary to demonstrate how philosophy and education combine each other inside socratic thought, in order to offer a theoretical board to think the praxis of educator's auto breeding, who must search his or her own intellectual and moral excellence both such as a person either such as a professional, that is, he or she must look for virtue, in order to be coherent with his or her ideals and actions.

Since Antiquity, Socrates was already known such as someone who, instead of having just taught philosophy, he had lived it, according to the testimony that has come to us from Diogenes Laércio (2007). For this reason, Socrates is unavoidably conceived such as the standard, for excellence, of the practical philosopher, who is not satisfied with, as well as neither admits, unprofitable and inutile speculations, which contribute for nothing considering the intellectual and moral improvement of human being. Thus, his preoccupation with human practical problems, mostly the ethical (moral) and

*Professor, University of Uberaba, Brazil. 
politic (civic) ones, made of his reflection one of the main water divisors in the ambit of the history of philosophy as well as in the ambit of the history of education.

The reason for which here one defends Socrates as an innovator, both in philosophy and in education, it is based on his peculiar investigation method:

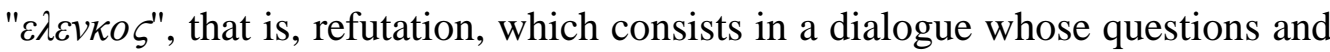
answers concerning determined theme, at the end of that one should fatally make option for rejection of some thesis or affirmation, after being found its logic inconsistence or incoherence. This method, essentially dialogical, remains valid until today to philosophers and educators, who bet that, only starting from a dialogical perspective, one will be able to reach agreement, indispensable element to consolidation both to philosophical thought in general either to educational practice in particular, reason by which this text advocates the importance of knowledge about socratic thought as a philosophical fundament to educator's breeding.

\section{The Process of Creation of Socratic Philosophy and Pedagogy}

It is surely unknown when, how and why Socrates has become a philosopher; there are both anecdotes either serious affirmations regarding the reasons that would have driven him to make philosophy his life work. Moreover, it is very complicated to admit the historicity of his person, despite his unquestionable importance to the history of western philosophical and pedagogical thought; according to the testimony of Professor Jean Brun.

Socrates' person puts to the philosopher a quite strange problem but full of sense: all the history of Greek philosophy is traditionally organized around his name and we do not know who Socrates really was, there is no history of Greek thought but in function of Socrates' character and history does not allow us to make of him a historic character. (Brun, 1984, p. 9; our English version)

Howsoever, the fact is that, starting from him, the philosophical activity has been extended to the ambit of questions typically human, especially those ones of ethical-political order. Although Socrates has not left behind him anything written of his own fist, his thought has been passed centuries and has come to present days, both because of his followers, such as Plato ${ }^{1}$ (428/7-

\footnotetext{
${ }^{1}$ Plato is, without shadow of doubt, the historic character who explored Socrates on the best way, both to describe him on his person and/or only to express his own thought, either to make of him the main issuing of his own ideas. His wide work, almost composed of dialogues, allows to affirm that: "There is not almost a platonic dialogue into which Socrates does not figure, in the most part he is who conducts the discussion and the interlocutors are always fully beated by his argumentation and irony. Works such as Apology of Socrates, Criton and Fedon can purport precious testimonies which allow us to fix more than a point of Socrates' biography" (Brun, 1984, p. 14; author’s italicizes; our English version).
} 
348/7 B.C) and Xenophon ${ }^{1}$ (c. 430-355 B.C), either because of the mediation of his scoffers, whose the greatest example is the comedies writer Aristophanes $^{2}$ (c. 447-385 B.C).

Leaving aside the issue concerning the real or imagined existence of Socrates, which here is emphasized is the fact of thinking that is ascribed to him is one of the great watersheds, not only for Philosophy in Classical Antiquity, but for History of Philosophy in general and, particularly, have been constituted as a fertile and enduring theoretical foundation for education. So, here we will not occupy whether, in fact, Socrates existed or not: what really is relevant to the purpose of this paper is to show in what measure all that Socrates represents becomes meaningful to do with that philosophy and education converge to the same purpose, namely: the reflexive or examined life, which is a process of introspection, after which the individual will be driven mostly by himself to the possession of virtue.

Thus, it appears that, in Socrates, virtue is the principle on which parts the whole of his speculations, given that it is precisely assuming its existence, its knowledge and its practice that the Athenian thinker proposes to philosophize in order not to end somewhat different from the own virtue. Moreover, virtue is also the ultimate end for which converge his thinking, which is why philosophy is constituted, from his perspective, as the highest form of education for virtue. However, it should be noted that the Socratic virtue is not confined to the limits of Homeric virtue, from the heroic and aristocratic times, nor the boundaries of political virtue, identified as the whole field of persuasion techniques, intensely widespread in his time.

The concept of virtue heralded by Socrates seeks to combine the Homeric nobility with sophistry dexterity, adding that the real nobility would be the result of a high character, intellectually and morally educated, in order to place the individual who holds it in a position to be beautiful and good, not only in view of his or her personal interests or advantages, but mainly the interests or benefits for the city-state, from which he or she is a citizen, and, likewise, the field of persuasion techniques would not have the required purpose only victory in any verbal event (priority of the Sophists), but rather convince the guy on the knowledge of truth and the practice of virtue, since it would be his or her true happiness.

1 Jean Brun (1984, p. 16), relying on the testimony of Diogenes Laertius, relates how Xenophon and Socrates would have been found each other for the first time, when the first, across a narrow street of Athens, found the second, who would have done the following question to him: "Where do you buy the things needed for life?", before the response of Xenophon, Socrates undertook another question: "Where did you learn to be an honest man?" This time, because there was no response from Xenophon, Socrates, then, would have called him in these terms: "Come with me and I will teach thee."

${ }^{2}$ In one of his comedies, entitled The Clouds, Aristophanes depicts Socrates, as claimed by Jean Brun (1984, p. 20), so much ridiculed, caricaturing him as a lazy and bad tempered guy, a wicked and blasphemous sophist, devoted to investigate and make their followers investigate useless, futile and sterile problems, beyond being described as someone who abuses the ingenuity of his disciples. 
Whichever here we add from Dinucci: For Socrates, happiness is gradually achieved through philosophizing. Thus, the relationship between virtue and happiness, in Socrates, is an identity relation, then, by virtue, man acts in a good and beautiful manner and therefore is happy, and no matter absolutely what matters has before him over which it exercises virtue. The possession of virtue is happiness for man, his absence, unhappiness. Everything else is relative to it; nothing added or removed with respect to happiness, which means to have moral virtue (Dinucci, 2009, p. 262; our English version).

Therefore, Socrates announces that nobility that he considers true is not one that comes from a divine lineage, in the same way that refuses to admit as virtuous someone who is merely skillful in persuading or dissuading; there is in his thought an intellectual and moral requirement much more intense, because, for him, philosophy is to educate the individual, in a way that he or she may endeavor to be perfected gradually, resulting in it his or her nobility or virtue. Thus, Socrates argues that virtue is nothing but a knowlege, but not a knowledge any one, since it dealt with something both practical and theoretical, that is, it consists of a thought and an action both coherent between themselves.

If virtue is knowledge for Socrates, it is because the action involves a reflected discernment that allows us not confuse the desire and will, the subjective assessment with the true value, the individual opinion with motivated knowledge. Thus, on the one hand virtue is a knowledge and on the other hand it cannot be learned as one learns the multiplication table, which is why we see numerous examples of good men who could not teach their children that virtue that themselves practiced. Knowing that virtue requires is a knowledge that is not acquired as knowledge of grammar, it implies a work of inner conversion that anyone can do for us, but that the philosopher can make us discover the urgent need (Brun, 1984, p. 11-112; our English version).

Given that quote, it is observed that Brun, to clarify what kind of knowledge is the socratic virtue, however, he allows to glimpse at least two important issues, namely: "Whether virtue cannot be taught the same way as taught some other kind of knowledge (for example, a multiplication table), so how it can be learned, known and practiced?" and: "What then would be the master role, since he or she cannot transmit virtue to his disciple?"

In order to answer those questions, one can show that: although virtue is a knowledge, it does not mean that it is something teachable, because for Socrates, virtue knowledge is the result of a deep interior search, which everybody (and only he or she) needs to do into the core of his or her own being, in order to it may bring to him or her self-knowledge, which nobody will be able to reach instead of him or her, reason by which virtue is not taught but it can be encouraged in order to be looked for by himself or herself. Thus, the 
master's function would be moved from the knowledge holder pole to the pole of the encourager of learning search, that is: master is someone who, in relation to virtue, he or she stimulates and orients his or her apprentice on his or her search for himself or herself, at the end of it he or she will find knowledge about himself or herself.

According to add Cambi, referring to educational intention of Socrates' philosophy: [...] we are before a paideia as problematization as research, which aims an individual in constant maturation of itself, welcoming inside the master's voice and making a master of itself. Human formation is to Socrates maieutics (operation from inside to outside) and a dialogue which is done by a master (so be it Socrates or an inside daimon), which awakens, raises doubts, requires research, drives, problematizes etc by dialogue, which opens to dialectics (to unification through opposition, constituting an unity which tends to become richer more and more). Socrates' educative action consists on favoring this dialogue and its radicalization, on requiring more and more concepts improvement in order to arrive to a more universal and critical formulation. Thus, it is done the "bringing out" of the personality of each individual who has as objective the "know thyself" and its realization according to the principle of freedom (Cambi, 1999, p. 88; author's italicizes and bold; our English version).

Once refusing the capacity of teaching something to someone, Socrates looks for calling attention to this: which method should, then, be employed in order to his interlocutor may be able to have conditions to be well guided and, thus, to arrive to the knowledge of truth as well as to the practice of virtue.

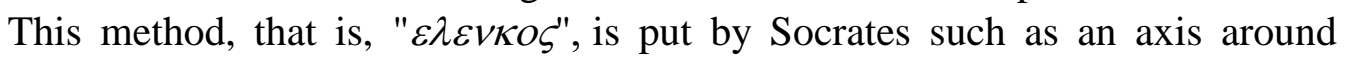
which gravitate his ruminations, driven to that individual should know and practice, as in relation to itself (thence the ethical or moral character of his speculation), as in relation to society of which he or she is part (thence follows the political or civic nature of his reflection). On this consists the socratic philosophical and pedagogical mission: to employ the adequate method, that is, refutation, as to rout knowledge presumption as to drive the individual to that he or she intends to know in essence, not only in appearance; just like that one could be safe in order to offer to individual an education which will be able to become it beautiful and good, as to itself as to its City-State.

Here we include a Cambi's quote, who masterfully concludes what was specifically shown inside this paragraph: Socrates' paideia is problematic and open; but fixs the itinerary and the structures of the process with the choices that the subject should perform; it consigns a dynamic and dramatic formation standard, but at the same time individual and universal one. We are before a model of paideia among the most linear 
and dense ones, because Socrates very know the personal character of formation, its process full of tensions, its tendency to self-government and self-direction and the fact of being a continuous task. The "pedagogy of individual consciousness" oriented by philosophy (typical of Socrates) qualifies such as, perhaps, the most mobile and original model produced by classical age; characteristics that, for millennia, will become that model pragmatic and able to focus in deepness on all western pedagogical tradition (Cambi, 1999, p. 88-89; author's italicizes and bold; our English version).

\section{The Legacy of Socratic Philosophy and Pedagogy to Educator's Auto- Breeding (Final Considerations)}

History of Philosophy and History of Education have a priceless debt with Socrates. His thought, as into his material (thematic) aspect as into his formal (methodological) one, constitutes in its set a peremptorily challenging problematics to philosophers and educators over eras, because his weighing questions any perspective which intends to jail knowledge, in a way to circumscribe it such as a professionals' prerogative; that is: Socrates refuses that knowledge should be something jailed and sold by specialized individuals; its proof is that he own claimed that he had never been paid to dialogue with anyone.

Lover of a good conversation and always available to one, he looked constantly for somebody with whom he could dialogue and, thus, he never dodged himself to the task of helping individuals in order to make them to reflect by themselves, conceiving, at the end, their own thoughts, his maieutics consists on it, and on the same way, his incisive and disquieting questions ridicule who hoisted as sages, reducing them to shame, because they were forced to admit their own ignorance, there is the nature of his irony, so, Socrates has become an insuperable model of intellectual humility, because he never pronounced himself as a sage, because he perceived that he just knew that he knew nothing; moreover, his permanent moral exhortations have made of him the Athenian knight of virtue, because he admonished his fellow citizens in order to not occupy themselves with their bodies and material possessions firstly, but so with virtue, because it would result in them.

Nothing else I do but walk thereabouts convincing you, young and old men, to not caring so hardly your body and riches, but so how to improve as much as possible the soul, telling you that virtue does not come from possessions to men, but from virtue comes possessions and all other particular and public goods (Plato, 2004, p. 57).

Socrates is, for excellence, the dialogue philosopher and educator; he bets that there is the key to individual and collective progress of human being, as materially as spiritually. Without any pretention of self-naming himself sage or 
master, although he is considered by others such as one (and here we are included), he leaves his message which crosses eras; this message consists on the points which we mention hereafter, which can be considered prolific references in order to educator may think and rethink his or her own formation, supported by socratic reflection; they are:

1. Knowledge belongs to mankind, not only to a privileged portion of it; so, depriving a human being of knowledge means to infringe it a capital right.

2. Knowledge is free; consequently, it is not to be bargained or commercialized, being, thus, illicit to be enriched due to it, there is here his condemnation to sophists.

3. The principle of knowledge is to recognize his or her own ignorance; so, who intends to become a sage, make of himself or herself an ignorant; who intends to become a master, make of himself or herself a disciple.

4. Knowledge and virtue identify each other; thus, it is not correct to claim that somebody is wise without being virtuous; on the same way, it is wrong to affirm that somebody is virtuous not being wise.

5. Virtue and happiness amount each other, that is, the virtuous conduct is rewarded by itself; therefore, virtue is a happy behavior; ipso facto, it does not mean to look happiness for without virtue, on the same way that it is a nonsense to look virtue for after reaching happiness, such as if the second one could be out of the first one.

6. Philosophy and pedagogy maintain between each other a dialectic relation, that is: there is a dialogue between them, which benefit both, because it is possible to philosophize in order to educate on the same way that it is possible to educate to philosophize.

7. Philosopher and educator are dialogue agentes; therefore, being the dialogue the common factor between philosophy and education, on the measures that both serve themselves from it they will contribute to prosperity both to philosophical activity either to educational one.

\begin{abstract}
Aknowledgement
This article has been supported with the help of FAPEMIG (Foundation for supporting research of Minas Gerais State), to whom we would like to express our gratitude, respect and recognition.
\end{abstract}


Vol. 2, No. 2 Batista: Socrates: Philosophy applied to Education-Search for Virtue

\section{References}

Brun, J. (1984). Sócrates [Socrates]. Lisboa: Dom Quixote.

Cambi, F. (1999). História da Pedagogia [ History of Pedagogy]. São Paulo: Editora UNESP.

Dinucci, A. (2009). A relação entre virtude e felicidade em Sócrates [The relationship between virtue and happiness in Socrates] In: Filosofia Unisinos. 10(3), 254-264.

Laércio, D. (2007). Vidas de los filósofos ilustres [Lives of the illustrious philosophers]. Colección Clássicos de Grécia y Roma. Madrid: Alianza.

Plato (2004). Apologia de Sócrates [Apology]. São Paulo: Nova Cultural. (Os Pensadores) 